\title{
A novel ex vivo high-throughput assay reveals antiproliferative effects of idelalisib and ibrutinib in chronic lymphocytic leukemia
}

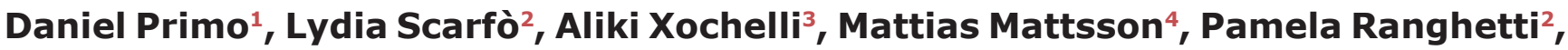 \\ Ana Belén Espinosa ${ }^{1}$, Alicia Robles ${ }^{1}$, Julian Gorrochategui ${ }^{1}$, Joaquín Martínez- \\ López $^{5}$, Javier de la Serna ${ }^{5}$, Marcos González ${ }^{6}$, Alberto Chaparro Gil7,11, Eduardo \\ Anguita ${ }^{7,11}$, Sandra Iraheta $^{8}$, Veerendra Munugalavadla ${ }^{9}$, Christophe Quéva ${ }^{9}$, \\ Stacey Tannheimer ${ }^{9}$, Richard Rosenquist ${ }^{4,10}$, Kostas Stamatopoulos ${ }^{3,4}$, Joan \\ Ballesteros ${ }^{1}$ and Paolo Ghia ${ }^{2}$

\footnotetext{
${ }^{1}$ Vivia Biotech, Tres Cantos, Madrid, Spain

${ }^{2}$ Strategic Research Program on CLL and B Cell Neoplasia Unit, Università Vita-Salute San Raffaele and IRCCS Istituto Scientifico San Raffaele, Milan, Italy

${ }^{3}$ Institute of Applied Biosciences, Center for Research and Technology Hellas, Thessaloniki, Greece

${ }^{4}$ Department of Immunology, Genetics and Pathology, Science for Life Laboratory, Uppsala University, Uppsala, Sweden

${ }^{5}$ Department of Hematology, Hospital Universitario 12 de Octubre, Madrid, Spain

${ }^{6}$ Hematology Service, IBSAL-Hospital Universitario, Centro de Investigación del Cáncer (CIC)- IBMCC, Centro de Investigación Biomédica en Red de Cáncer (CIBERONC), Universidad de Salamanca, Salamanca, Spain

${ }^{7}$ Department of Hematology, Hospital Clínico San Carlos, Instituto de Investigación Sanitaria San Carlos (IdISSC), Madrid, Spain

${ }^{8}$ Department of Hematology and Hemotherapy, Hospital Universitario de Canarias, La Laguna, Spain

${ }^{9}$ Gilead Sciences, Foster City, CA, USA

${ }^{10}$ Department of Molecular Medicine and Surgery, Karolinska Institutet, Stockholm, Sweden
} \\ ${ }^{11}$ Department of Medicine, Universidad Complutense de Madrid (UCM), Madrid, Spain
}

Correspondence to: Joan Ballesteros, email: jballesteros@viviabiotech.com

Keywords: chronic lymphocytic leukemia; Ibrutinib; idelalisib; antiproliferative; ex vivo

Received: August 13, $2017 \quad$ Accepted: April 28, $2018 \quad$ Published: May 25, 2018

Copyright: Primo et al. This is an open-access article distributed under the terms of the Creative Commons Attribution License 3.0 (CC BY 3.0), which permits unrestricted use, distribution, and reproduction in any medium, provided the original author and source are credited.

\section{ABSTRACT}

PI3Kס (idelalisib) and BTK (ibrutinib) inhibitors have demonstrated significant clinical activity in chronic lymphocytic leukemia (CLL) interfering with the cross-talk between CLL cells and the lymph node microenviroment, yet their mechanism of action remains to be fully elucidated. Here, we developed an ex vivo model with the aim of reproducing the effects of the microenvironment that would help shed light on the in vivo mechanism of action of idelalisib and ibrutinib and predict their clinical efficacy in individual patients. First we explored the effects of various cell-extrinsic elements on CLL apoptosis and proliferation and found that the combination of CpG+IL2+HS5 stromal cell line + human serum + CLL plasma and erythrocyte fractions represented the best co-culture conditions to test the effects of the novel inhibitors. Then, using this assay, we investigated the impact of idelalisib and ibrutinib on both survival and proliferation in 30 CLL patients. While both drugs had a limited direct pro-apoptotic activity, a potent inhibition of proliferation was achieved at clinically achievable concentrations. Notably, up to $10 \%$ of CLL cells still proliferated even at the highest concentrations, likely mirroring the known difficulty to achieve complete responses in vivo. Altogether, this novel assay represents an appropriate ex vivo drug testing system to potentially predict the clinical response to novel inhibitors in particular by quantifying the antiproliferative effect. 


\section{INTRODUCTION}

The microenvironment critically promotes the development and progression of CLL, favoring leukemic cell survival and proliferation as well as inducing drug resistance [1-3]. Therefore, in order to predict more reliably the actual clinical (i.e. in vivo) response to drugs by analyzing primary CLL cells ex vivo, it is essential to develop assays that would take into account the key role of the microenvironment as well as the pharmacology of the drugs.

Several co-culture systems have been used in the past to simulate the in vivo microenvironment aiming to reproduce the proliferative signals of the socalled "proliferation centers" [4-10]. Combinations of cytokines and soluble molecules, such as $\mathrm{CD} 40 \mathrm{~L}+\mathrm{CpG}$ [11], CD40L+IL21 [12], CpG+IL2 [13, 14], alone or in combination with stromal cell lines [11,15], have been used to reproduce the stimuli provided by the microenvironment, however, definitive conclusions have not been reached. The need for more appropriate ex vivo assays is particularly relevant nowadays in order to assess the actual mechanism of action of novel targeted drugs such as the B cell signaling inhibitors idelalisib (a PI3K- $\delta$ inhibitor) $[16,17]$ and ibrutinib (a BTK inhibitor) [18-22] and predict ex vivo the anti-leukemic effect that may be achieved in vivo. These drugs act through distinct mechanisms compared to standard chemotherapy and monoclonal antibodies that are not yet fully understood but appear to be critically dependent on the surrounding microenvironment [16, 23, 24]. These inhibitors have already shown effects both in vitro and in vivo on cell survival, migration and proliferation [17-19, 25]. When administered to patients, both drugs appear to have a limited capacity to elicit cell apoptosis; indeed, using the current ex vivo assays, a proapoptotic effect on CLL cells is seen only at high micromolar concentrations difficult to attain in vivo $[16,26]$. On the contrary, apoptosis may be indirectly induced through the typical mobilization effect of the leukemic cells from the tissues to the blood, depriving the cells of the supportive action of the tissue microenvironment $[20,27,28]$. That notwithstanding, this cannot fully explain the sustained responses achieved with both drugs. Hence, it remains to be explained how and why these drugs are so beneficial when administered to patients.

In this study, we aimed at designing and validating an ex vivo co-culture system that simulates more closely the conditions present in the leukemic tissue microenvironment and enable not only CLL cell survival but also proliferation ex vivo. Such system would reproduce more accurately what is actually happening in vivo within the lymph nodes and, in particular, the events within the proliferation centers that are considered the reservoir of the disease. The herein described ex vivo assay incorporating microenvironmental stimuli enabled us to identify an anti-proliferative activity for idelalisib and ibrutinib that may underlie, at least in part, the effects of both drugs in vivo.

\section{RESULTS}

\section{Assessing ex vivo the impact of different combinations of stimuli on CLL apoptosis and proliferation}

In order to reproduce more closely the complexity of the in vivo microenvironment in CLL, we explored the effects of various microenvironmental mimicking elements on CLL cell survival and proliferation.

We previously reported that the native environment (NE), defined as the plasma and erythrocyte/granulocyte fraction of a Ficoll gradient is critical to prevent artifacts in ex vivo drug testing [29] offering higher predictive accuracy regarding clinical responses against acute myeloid leukemia [Montesinos et al, manuscript in preparation]. On these grounds, we explored the effect of the NE on CLL samples by testing pooled NE from 5 different healthy donors (HD) or 5 CLL patients on 11 cryopreserved CLL samples from 5 IGHV-unmutated (U-CLL), 5 IGHV-mutated (M-CLL) and lunknown. The decision to pool NE from different individuals was taken in order to minimize interpatient or interdonor variability. The median $\%$ of non-apoptotic cells after thawing was $62 \%$ (ranging 16-92).

With CpG and IL2 stimulation as backbone, given the well known proliferative effect on CLL leukemic cells [14], we found that the addition of NE, from HD or CLL patients decreased apoptosis (median \% of apoptotic cells without NE vs NE from HD vs NE from CLL: $28 \pm 27$ vs $19 \pm 23$ vs $5 \pm 17 ; p<0.001$ ), while the addition of the stroma cell line HS5 abrogated the positive effect of the NE resulting in similar protection from apoptosis in all 3 conditions (35\%) (Figure 1A). A different trend was observed regarding proliferation: in the presence of HS5, CLL cells exposed to NE from CLL showed a marked increase of the proliferation rate (median $\%$ of proliferating cells without NE vs NE from HD vs NE from CLL: $5 \pm$ 21 vs $22 \pm 21$ vs $40 \pm 25$ ) (Figure 1B). Therefore, the best combination of microenvironmental mimicking factors was achieved when including the NE from CLL patients. We also compared Human Serum (HS) 10\% vs FBS 10\% in 10 CLL samples in the presence of the NE from CLL patients and HS5, and observed that HS exerted a superior protective effect against apoptosis (median $\%$ of apoptotic cells with HS $10 \%$ vs FBS 10\%: $48 \pm 28$ vs $65 \pm 19$, $p=0.004)$. No significant differences were observed between U-CLL and M-CLL in this set of experiments. Based on these results, we decided to include NE from CLL and HS in all future assessments.

Capitalizing on the capacity of the PharmaFlow platform (formerly called ExviTech) to screen multiple conditions simultaneously [29], we next examined different combined microenvironmental mimicking triggers for their effects on CLL cells. To this purpose, cryopreserved PB samples from 7 U-CLL and 5 M-CLL CLL cases were tested for multiple conditions using 2 
additional backbone stimulations previously reported as effective in improving CLL proliferation and survival, besides CpG+IL2 [13, 14], namely sCD40L+CpG [11] and SCD40L+IL21 [12], along with the NE pooled from PB of CLL samples and HS (Table 1). The median \% of non-apoptotic cells after thawing was $88 \%$ (ranging 73-97). Then, in a stepwise fashion, we added to each of these combinations one or more of the following elements: BAFF, sCD40L, BcR stimulation (anti-IgM) and the HS5 stromal cell line.

Of all specific backbone stimulation tested, $\mathrm{CpG}+\mathrm{IL} 2$ provided better results in terms of protection from apoptosis and proliferation vs $\mathrm{sCD} 40 \mathrm{~L}+\mathrm{CpG}$ or $\mathrm{sCD} 40 \mathrm{~L}+\mathrm{IL} 21$ (Figure 2A). Incorporation of additional stimuli (BAFF, anti-BCR, sCD40L, HS5) to the CpG+IL2 combination consistently improved proliferation, however at a cost of increased apoptosis (Figure 2B), with the notable exception of the concomitant use of CpG+IL2 and HS5 (at 1:100 ratio) that showed the best effects with a median of $30 \pm$ $19 \%$ of apoptosis and $30 \pm 27 \%$ of proliferation in the 12 cryopreserved progressive CLL samples analyzed (Table 2 and Supplementary Figure 1). The lack of improvement in terms of proliferation when cells were stimulated through CD40 was confirmed in additional experiments using other soluble or multimeric sCD40L in the cocktail. Interstingly, in this co-culture model, HS5 cell line already express CD40L (Supplementary Figure 2) that could overcome the effect by exogenous addition of the soluble forms.

Although, overall, $\mathrm{CpG}+\mathrm{IL} 2+\mathrm{HS} 5$ proved to be the best combination, still it showed significant heterogeneity between samples regarding the protection from apoptosis (range, 7-70\%) and induction of proliferation (range, $1-91 \%)$. We investigated if this could be associated with particular, prognostically relevant, biological features of each CLL sample such as IGHV gene somatic hypermutation status, CD38 expression, and cytogenetic abnormalities detected by FISH. We found that U-CLL cases showed a significantly more prominent proliferative response ( $48 \pm 27 \%$ vs $17 \pm 14 \%$ for M-CLL; $p<0.001$ ); however, no significant differences were evident in terms of apoptosis, although U-CLL cases showed a trend for more homogeneous protection $(25 \pm 19$ vs $38 \pm 19$ in U-CLL vs M-CLL cases; $p=0.5$ ).

\section{Idelalisib and ibrutinib induce potent inhibition of $B$ cell proliferation}

Based on the previous results, the final combination, i.e. CpG+IL2+HS5 $(1: 100)+$ HS 10\% + pooled CLL NE, was used as an ex vivo assay in order to test the effect of idelalisib and ibrutinib on 30 cryopreserved samples from CLL patients in need of treatment (Table 3). We analyzed responses to both drugs after $96 \mathrm{~h}$; dose concentrations ranged from $150 \mu \mathrm{M}$ to $0.54 \mathrm{nM}$ to cover a wide window of concentrations.

In comparison to the co-culture condition where the number of cells increased due to augmented proliferation and decreased apoptosis, when cells where incubated in the presence of both idelalisib $(n=29)$ and ibrutinib $(n=25)$, the number of CLL cells was

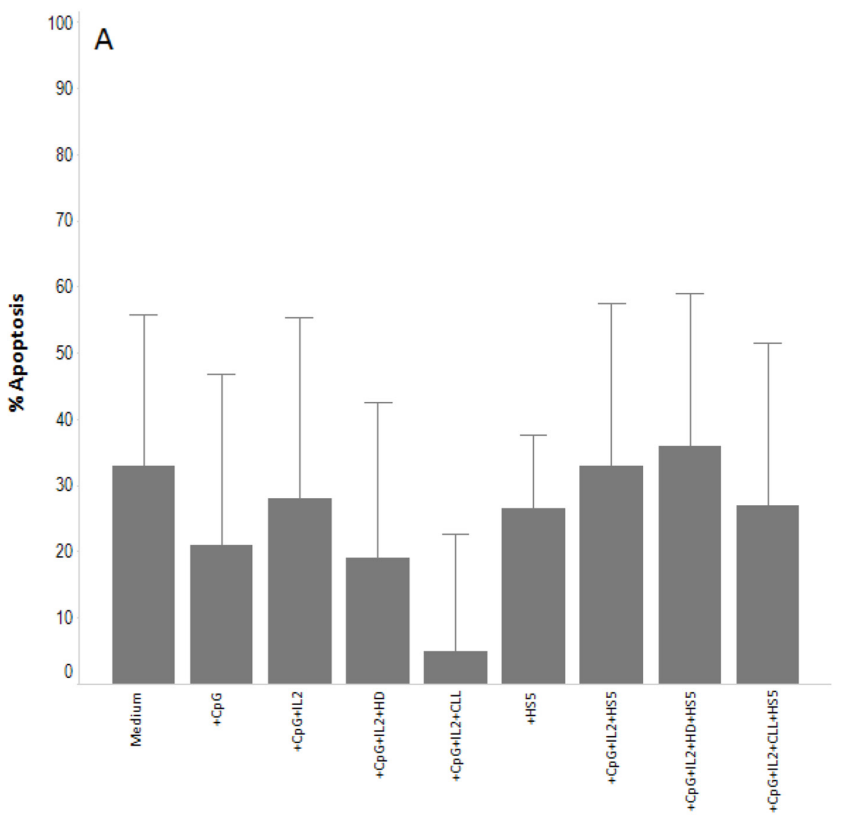

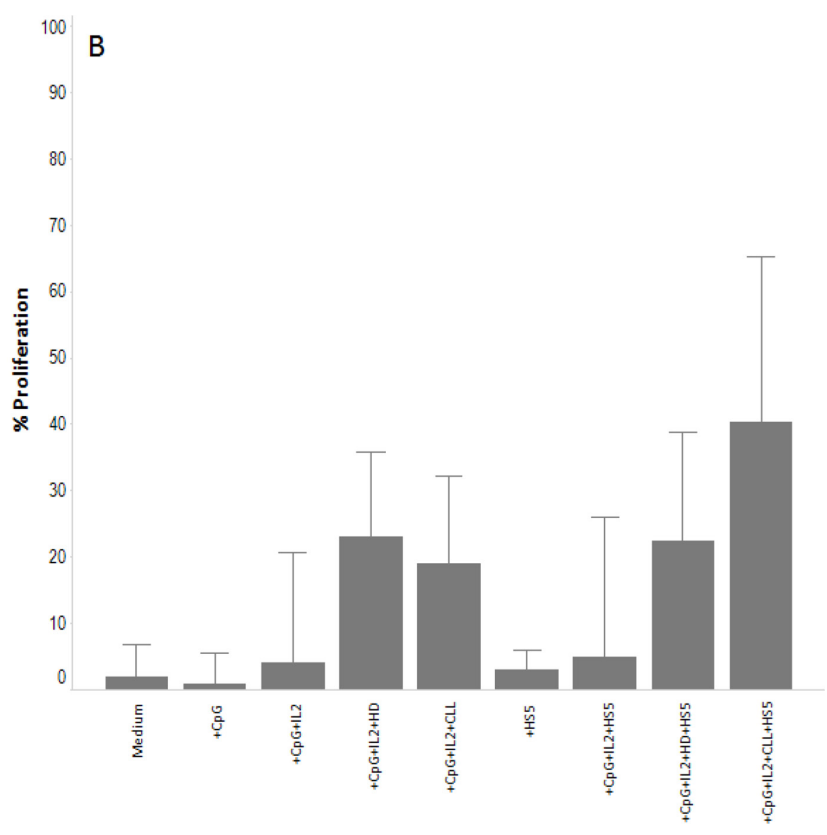

Figure 1: Effect of the NE on CLL apoptosis and proliferation. Histograms showing the effect on apoptosis and proliferation of the NE from 5 CLL or 5 HD in 11 cryopreserved CLL samples. (Panel A) show the apoptotic effect of the CpG+IL2 cocktail in presence of the different NE or HS5 cell line. (Panel B) show the proliferation effect of the CpG+IL2 cocktail in presence of the different NE or HS5 cell line. Data from apoptosis are subtracted from the value of apoptosis after thaw. Each condition was acquired in triplicate and data represent the median $\pm \mathrm{SD}$. 
Table 1: List of cytokine combinations tested to compare viability and proliferation

\begin{tabular}{lccc}
\hline No signal & $\begin{array}{c}\text { CD40L+CpG } \\
\text { Signalling }\end{array}$ & $\begin{array}{c}\text { CD40L+IL21 } \\
\text { Signalling }\end{array}$ & $\begin{array}{c}\text { CpG+IL2 } \\
\text { Signalling }\end{array}$ \\
\hline Medium & CD40L+CpG & CD40L+IL21 & CpG+IL2 \\
Medium+CLL NE & CD40L+CpG+Ig & CD40L+IL21+Ig & CpG+IL2+CD40L \\
Medium+HS5 & CD40L+CpG+BAFF & CD40L+IL21+BAFF & CpG+IL2+Ig \\
Medium+CLL NE+HS5 & CD40L+CpG+IL21 & CD40L+IL21+HS5 & CpG+IL2+HS5 \\
& CD40L+CpG+HS5 & CD40L+IL21+Ig+HS5 & CpG+IL2+BAFF \\
& CD40L+CpG+Ig+HS5 & CD40L+IL21+BAFF+HS5 & CpG+IL2+CD40L+HS5 \\
& CD40L+CpG+BAFF+HS5 & & CpG+IL2+Ig+HS5 \\
& CD40L+CpG+IL21+HS5 & & CpG+IL2+BAFF+HS5 \\
\hline
\end{tabular}

CLL: Chronic Lymphocytic Leukemia; NE: Native Environment.

significantly affected in a dose-dependent manner. In order to better understand the basis for these changes we analyzed proliferating vs non-proliferating fractions of CLL cells separately (Figure 3 ), and showed that activity for idelalisib and ibrutinib $\left(\mathrm{EC}_{50}\right.$ of $13.7 \pm 30.3 \mu \mathrm{M}$ and $13 \pm 21.2 \mu \mathrm{M})$ was overall evident on both fractions. A more detailed analysis showed that both idelalisib and ibrutinib led to a limited induction of apoptosis that was restricted to the non-proliferating fraction $\left(\mathrm{EC}_{50}\right.$ of 12.5 $\pm 22.5 \mu \mathrm{M}$ and $28.3 \pm 99 \mu \mathrm{M}$, respectively). In contrast, a potent and selective inhibition of proliferation was evident (average $\mathrm{EC}_{50}$ of $0.03 \pm 0.03 \mu \mathrm{M}$ for idelalisib and $0.55 \pm 1.6 \mu \mathrm{M}$ for ibrutinib), though the antiproliferative effect of either drug was never complete,

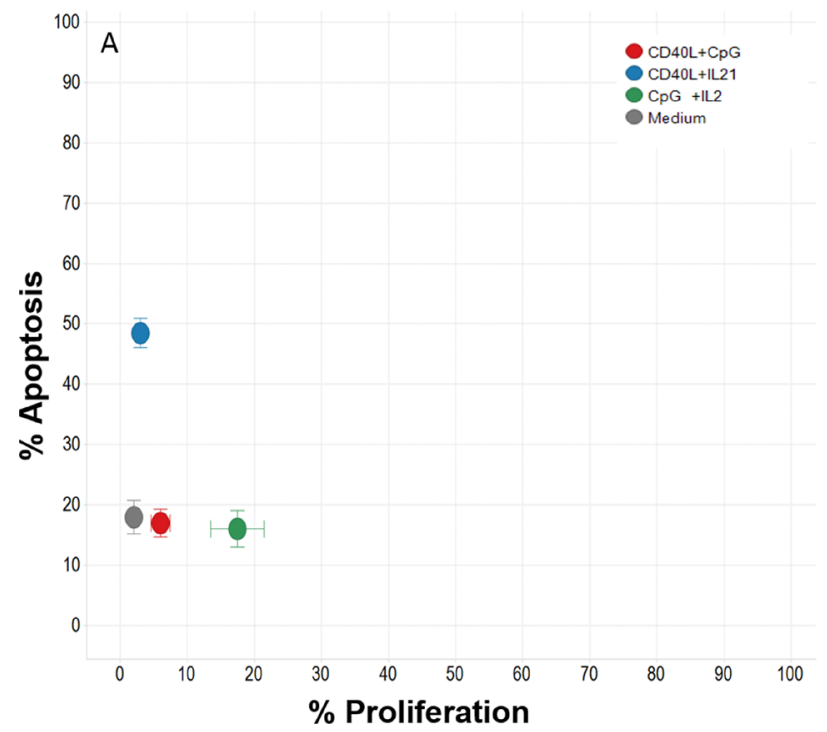

with an average of $5.2 \pm 5 \%$ and $8.8 \pm 11.7$ CLL cells, respectively, remaining in active proliferation even at the highest doses of either drug. High interpatient variability was apparent in the effect on proliferating cells, with distinct patterns for each drug. Ibrutinib showed 6/25 outlier samples displaying a lower ex vivo sensitivity relative to most of the other samples; 3 samples showed a substantially higher potency $\left(\mathrm{EC}_{50}\right)$ thus contrasting the other 3 samples where a substantially higher efficacy was noted $\left(\mathrm{E}_{\max }\right)$ (red-marked in Figure 4). Idelalisib showed a more homogenous pattern with few outliers. As a result, there was a higher variability in the standard deviation of ibrutinib vs idelalisib in the average values for potency $(1.6$ vs $0.03 \mu \mathrm{M})$ and efficacy (11.7 vs $5.2 \%)$.

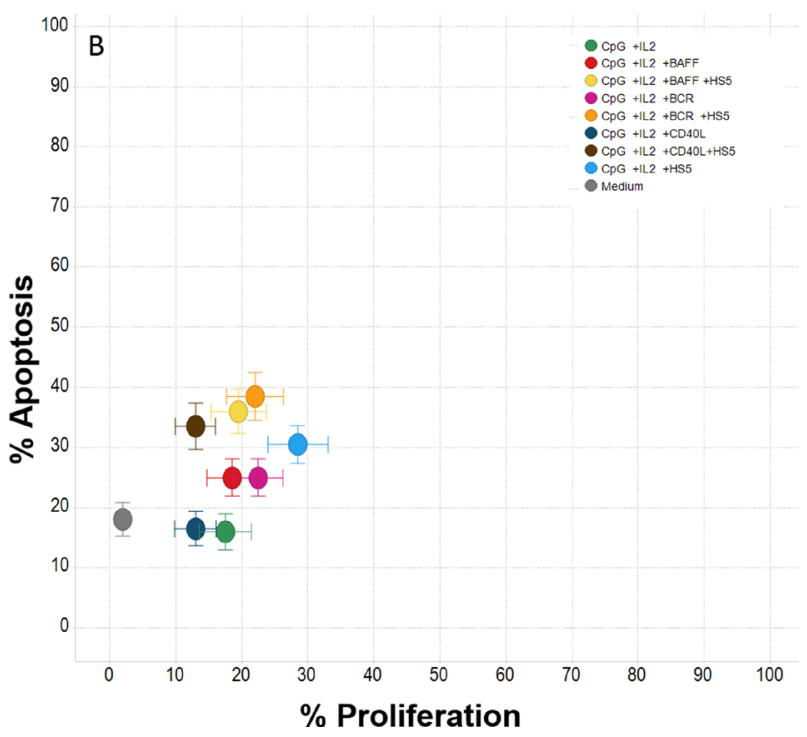

Figure 2: Effect of different cytokines on CLL apoptosis and proliferation. Twelve progressive CLL frozen samples (7 IGHV mutated and 5 unmutated) were used to test the effect of 26 different cytokine conditions with media containing a pool of 3 progressive CLL NE and human serum. (Panel A) shows the results of the 3 backbone stimulation (sCD40L+CpG, sCD40L+IL-21 and CpG+IL-2) in terms of apoptosis and proliferation reflecting that CpG+IL2 provided better results. (Panel B) shows the incorporation of additional stimuli (BAFF, anti-BCR, sCD40L, HS5) to the CpG+IL2 backbone stimulation reflecting that the use of CpG+IL2 and HS5 (at 1:100 ratio) showed the best effects with a median of $30 \pm 19 \%$ of apoptosis and $30 \pm 27 \%$ of proliferation. Data from apoptosis are subtracted from the value of apoptosis after thaw. 
Table 2: Percentage of apoptosis and proliferation of the cytokine combinations tested in 12 CLL

\begin{tabular}{lcc}
\hline Cytokine & \% Apoptosis & \% Proliferation \\
\hline Medium & $18 \pm 17$ & $2 \pm 1$ \\
Medium+CLL NE & $17 \pm 14$ & $2 \pm 1$ \\
Medium+HS5 & $27 \pm 17$ & $2 \pm 2$ \\
Medium+CLL NE+HS5 & $21 \pm 15$ & $2 \pm 3$ \\
CD40L+CpG & $17 \pm 14$ & $6 \pm 8$ \\
CD40L+CpG+Ig & $23 \pm 14$ & $5 \pm 7$ \\
CD40L+CpG+BAFF & $19 \pm 13$ & $7 \pm 8$ \\
CD40L+CpG+IL21 & $49 \pm 19$ & $6 \pm 11$ \\
CD40L+CpG+HS5 & $30 \pm 19$ & $5 \pm 13$ \\
CD40L+CpG+Ig+HS5 & $36 \pm 20$ & $4 \pm 12$ \\
CD40L+CpG+BAFF+HS5 & $39 \pm 22$ & $6 \pm 12$ \\
CD40L+CpG+IL21+HS5 & $62 \pm 20$ & $10 \pm 18$ \\
CD40L+IL21 & $48 \pm 14$ & $3 \pm 3$ \\
CD40L+IL21+Ig & $51 \pm 15$ & $2 \pm 1$ \\
CD40L+IL21+BAFF & $52 \pm 19$ & $2 \pm 4$ \\
CD40L+IL21+HS5 & $61 \pm 16$ & $3 \pm 3$ \\
CD40L+IL21+Ig+HS5 & $62 \pm 15$ & $4 \pm 4$ \\
CD40L+IL21+BAFF+HS5 & $64 \pm 19$ & $3 \pm 3$ \\
CpG+IL2 & $16 \pm 18$ & $18 \pm 24$ \\
CpG+IL2+CD40L & $16 \pm 17$ & $13 \pm 19$ \\
CpG+IL2+Ig & $25 \pm 19$ & $19 \pm 22$ \\
CpG+IL2+BAFF & $25 \pm 18$ & $19 \pm 22$ \\
CpG+IL2+HS5 & $30 \pm 19$ & $30 \pm 27$ \\
CpG+IL2+CD40L+HS5 & $33 \pm 23$ & $14 \pm 17$ \\
CpG+IL2+Ig+HS5 & $38 \pm 24$ & $23 \pm 25$ \\
CpG+IL2+BAFF+HS5 & $36 \pm 22$ & $20 \pm 25$ \\
\hline Data fomapoptosis & 19 & \\
& &
\end{tabular}

Data from apoptosis are subtracted from the value of apoptosis after thaw. Results are represented as median $\pm \operatorname{SD}(N=12)$.

To further study these different profiles, we compared effects in 14 samples where both drugs could be tested simultaneously ex vivo (Figure 4), including the 6 previously mentioned 'ibrutinib outliers' plus 8 additional cases. As expected, the 6 'ibrutinib outliers' cases showed a significant higher Area Under the Curve (AUC) for ibrutinib compared to the remaining 8 cases $(3503 \pm$ 1616 vs $747 \pm 418, p<0.001$ ), suggesting lower ex vivo sensitivity to the drug. Interestingly, the latter 8 samples did not show any outlier with low sensitivity to idelalisib, although higher AUCs were also observed $(1423 \pm 767$ vs $535 \pm 513, p=0.02 ;$ Figure 4).

Next, we analyzed if the ex vivo sensitivity to either idelalisib or ibrutinib could be associated to the biological profile of the studied cases (Table 4). No significant association was identified with any evaluated parameters [clinical stage, IGHV gene somatic hypermutation status, CD38 expression, trisomy 12, del(13q), del(11q), del(17p)]. Surprisingly, isolated del(13q), traditionally considered as prognostically favorable, was associated with a worse ex vivo response as evidenced by a significant higher AUC for both idelalisib (1670 vs 577, $p=0.01)$ and ibrutinib ( 3507 vs $1174, p=0.02$ ). These results indicate that both idelalisib and ibrutinib are effective in inhibiting CLL cell proliferation ex vivo even in cases with adverse biological background and, moreover, that this assay may help identifying the drug to which each case may best respond.

\section{DISCUSSION}

Novel drugs, such as, ibrutinib [30-32], idelalisib [33-35] and venetoclax [36], have been recently approved for clinical use in CLL, while many other drug candidates are currently in late-stage clinical development [37-39]. In most instances, these novel compounds act through 
Table 3: Clinical features of the CLL patients included to test idelalisib and ibrutinib in the study

\begin{tabular}{|c|c|c|c|c|c|c|c|c|}
\hline $\begin{array}{l}\text { Patient } \\
\text { Code }\end{array}$ & Gender & Age & $\begin{array}{c}\text { Stage } \\
\text { (Binet) }\end{array}$ & $\begin{array}{c}\text { IGHV SHM } \\
\text { status }\end{array}$ & FISH & CD38 & $\begin{array}{c}\text { Subsequent } \\
\text { need of therapy }\end{array}$ & $\begin{array}{c}\text { Previous } \\
\text { Treatment } \\
\end{array}$ \\
\hline 1 & Male & 51 & B & Unmutated & Normal & Negative & Yes & No \\
\hline 2 & Male & 54 & A & Unmutated & $\operatorname{del}(11 q)$ & Positive & Yes & Yes \\
\hline 3 & Male & 81 & $\mathrm{C}$ & Unmutated & $\begin{array}{l}\operatorname{del}(13 q) \\
\operatorname{del}(17 p)\end{array}$ & Positive & Yes & No \\
\hline 4 & Male & 53 & $\mathrm{C}$ & Mutated & $\operatorname{del}(13 q)$ & Positive & Yes & Yes \\
\hline 5 & Male & 64 & B & Mutated & $\operatorname{del}(17 p)$ & Negative & Yes & No \\
\hline 6 & Female & 68 & A & Mutated & Normal & Negative & Yes & No \\
\hline 7 & Female & 75 & A & Unmutated & N/A & Negative & Yes & No \\
\hline 8 & Male & 69 & $\mathrm{C}$ & Unmutated & $\operatorname{del}(17 p)$ & Negative & Yes & Yes \\
\hline 9 & Female & 72 & B & Unmutated & Trisomy 12 & Negative & Yes & No \\
\hline 10 & Male & 59 & $\mathrm{C}$ & Mutated & Trisomy 12 & N/A & Yes & Yes \\
\hline 11 & Male & 61 & A & Mutated & $\operatorname{del}(11 q)$ & Negative & Yes & Yes \\
\hline 12 & Male & 44 & A & Mutated & $\operatorname{del}(13 q)$ & Negative & Yes & Yes \\
\hline 13 & Male & 69 & A & Unmutated & N/A & Positive & Yes & Yes \\
\hline 14 & Male & 76 & A & Unmutated & $\operatorname{del}(11 q)$ & Positive & Yes & Yes \\
\hline 15 & Male & 67 & A & Mutated & Normal & Negative & Yes & Yes \\
\hline 16 & Male & 80 & A & Unmutated & Trisomy 12 & Positive & No & No \\
\hline 17 & Female & 87 & A & Mutated & N/A & Negative & Yes & Yes \\
\hline 18 & Female & 74 & A & Unmutated & $\operatorname{del}(11 q)$ & Negative & Yes & Yes \\
\hline 19 & Male & 66 & A & Unmutated & $\operatorname{del}(17 p)$ & Negative & Yes & Yes \\
\hline 20 & Female & 80 & B & N/A & Trisomy 12 & Positive & Yes & Yes \\
\hline 21 & Male & 84 & $\mathrm{C}$ & Mutated & $\operatorname{del}(13 q)$ & Negative & Yes & No \\
\hline 22 & Female & 32 & B & Unmutated & Normal & Negative & Yes & Yes \\
\hline 23 & Female & 73 & A & N/A & $\operatorname{del}(13 q)$ & Negative & Yes & Yes \\
\hline 24 & Female & 61 & A & Unmutated & $\operatorname{del}(17 p)$ & Positive & Yes & Yes \\
\hline 25 & Male & 42 & A & Unmutated & $\operatorname{del}(13 q)$ & N/A & Yes & N/A \\
\hline 26 & Female & 75 & A & Unmutated & $\operatorname{del}(11 q)$ & Positive & Yes & N/A \\
\hline 27 & Male & 47 & A & Unmutated & N/A & N/A & Yes & N/A \\
\hline 28 & Male & 57 & A & Mutated & Normal & Positive & No & No \\
\hline 29 & Male & 66 & $\mathrm{C}$ & Mutated & $\operatorname{del}(13 q)$ & Negative & Yes & No \\
\hline 30 & Male & 63 & B & Unmutated & $\operatorname{del}(17 p)$ & Negative & Yes & No \\
\hline
\end{tabular}

N/A: Not analyzed.

mechanisms different from classic chemo-immunotherapy, targeting fundamental pathophysiologic mechanisms and processes, e.g. signaling pathways which mediate microenvironmental interactions critical for CLL cell survival and proliferation. Despite the remarkable efficacy of the signaling inhibitors approved for clinical use, i.e. the PI3K $\delta$ inhibitor idelalisib and the BTK inhibitor ibritinib, several issues remain unresolved, especially regarding their precise mode of interaction with the microenvironment. This may be relevant for understanding why they are generally unable to lead to complete responses $(\mathrm{CR})$ and, even if $\mathrm{CR}$ is achieved, to eradicate minimal residual disease. Such comprehension has been hampered by the lack of suitable ex vivo pharmacological assays that may allow to recapitulate ex vivo the in vivo action of these new agents. Such assays may also be useful to predict in vivo efficacy, personalize treatment and test potential combinations for overcoming resistance.

Our study revealed that factors within the NE, i.e. Ficoll fractions of plasma and red blood cells (RBC)/ granulocytes, from the peripheral blood of patient samples, greatly protect CLL cells from apoptosis ex vivo. 

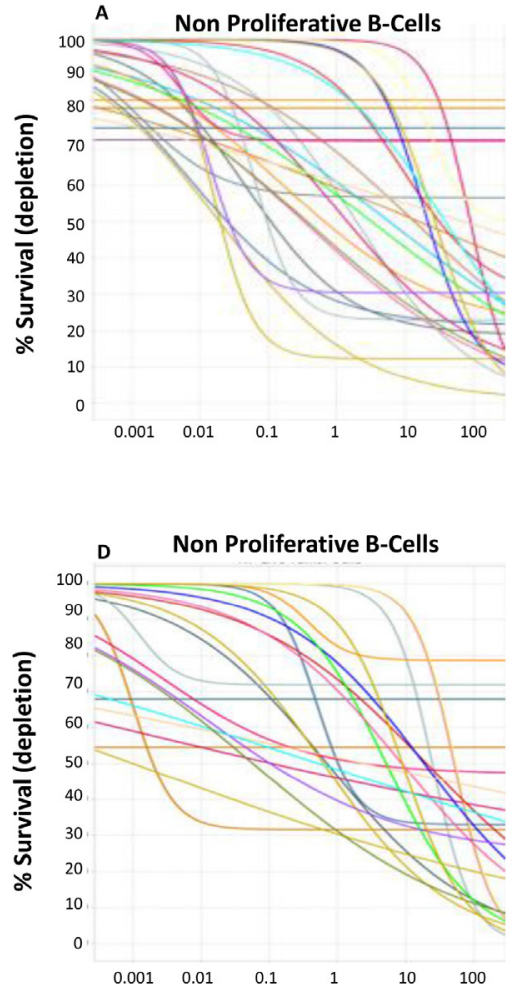
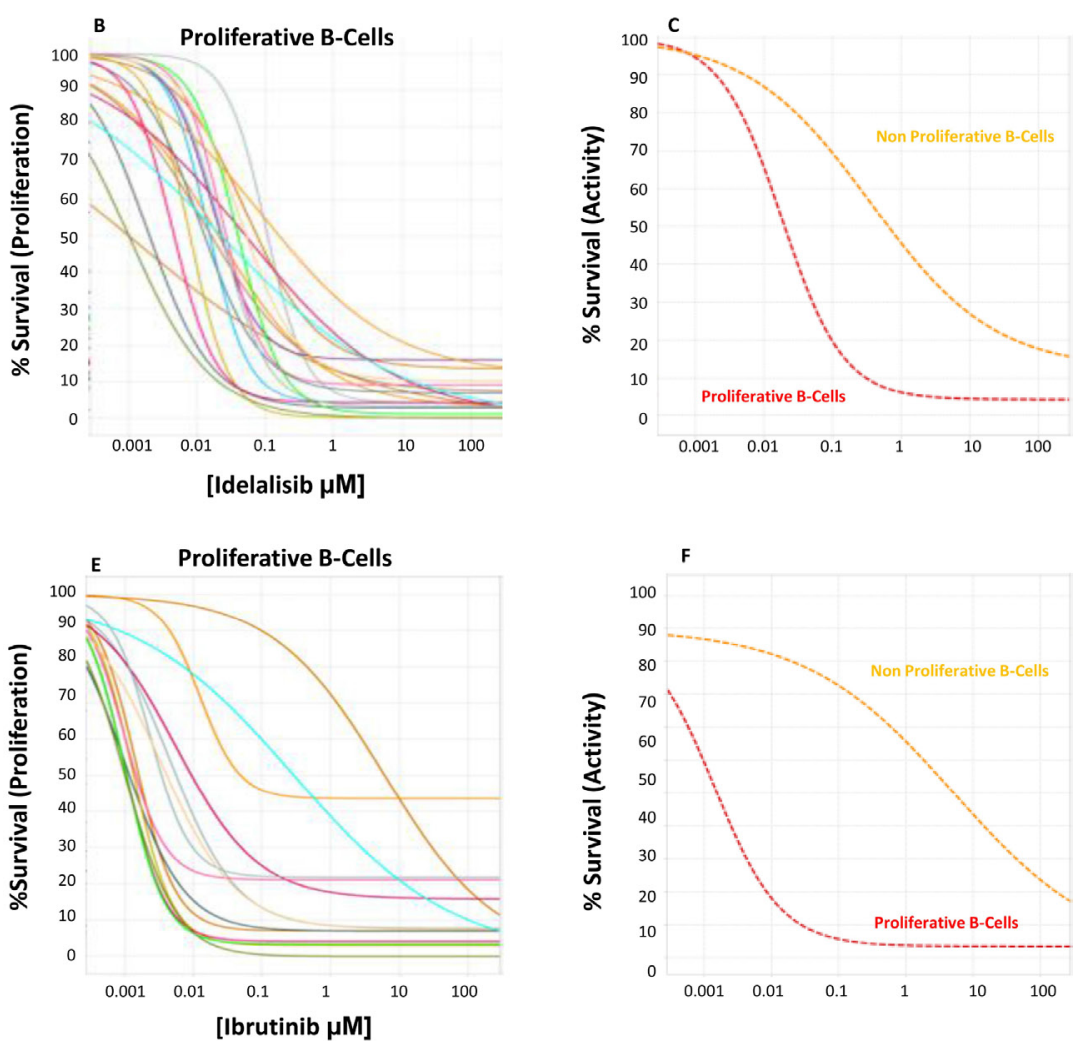

Figure 3: Idelalisib dose exposure evaluation. Twenty-nine progressive CLL frozen samples (represented with differently colored lines) were tested at $96 \mathrm{~h}$ with the $\mathrm{CpG}+\mathrm{IL} 2+\mathrm{HS}+\mathrm{CLL}$ NE media for dose response of idelalisib (Panels A-C) and ibrutinib (Panels D-F) in both the non-proliferative (panel A, D) and proliferative (panel B, E) fractions, measuring the $\%$ of live leukemic cells at each concentration shown as \% Survival. We found little effect on the non-proliferative CLL fraction, suggesting a limited pro-apoptotic depletion activity of the drugs. In contrast, potent inhibition of proliferation with median potency $\left(\mathrm{EC}_{50}\right)$ of $28 \mathrm{nM}$ for idelalilisib and $550 \mathrm{nM}$ for ibrutinib was observed. The efficacy was nearly complete leaving a median of $5 \%$ and $8 \%$ resistant CLL cells that proliferated at the highest doses of idelalisib or ibrutinib. (Panel C) (idelalisib) and (Panel F) (ibrutinib) represents the media of the effect in the non-proliferative CLL cells (orange line) and the proliferative B-fraction (red line) showing a predominant antiproliferative activity of both drugs.

Idelalisib

Ibrutinib

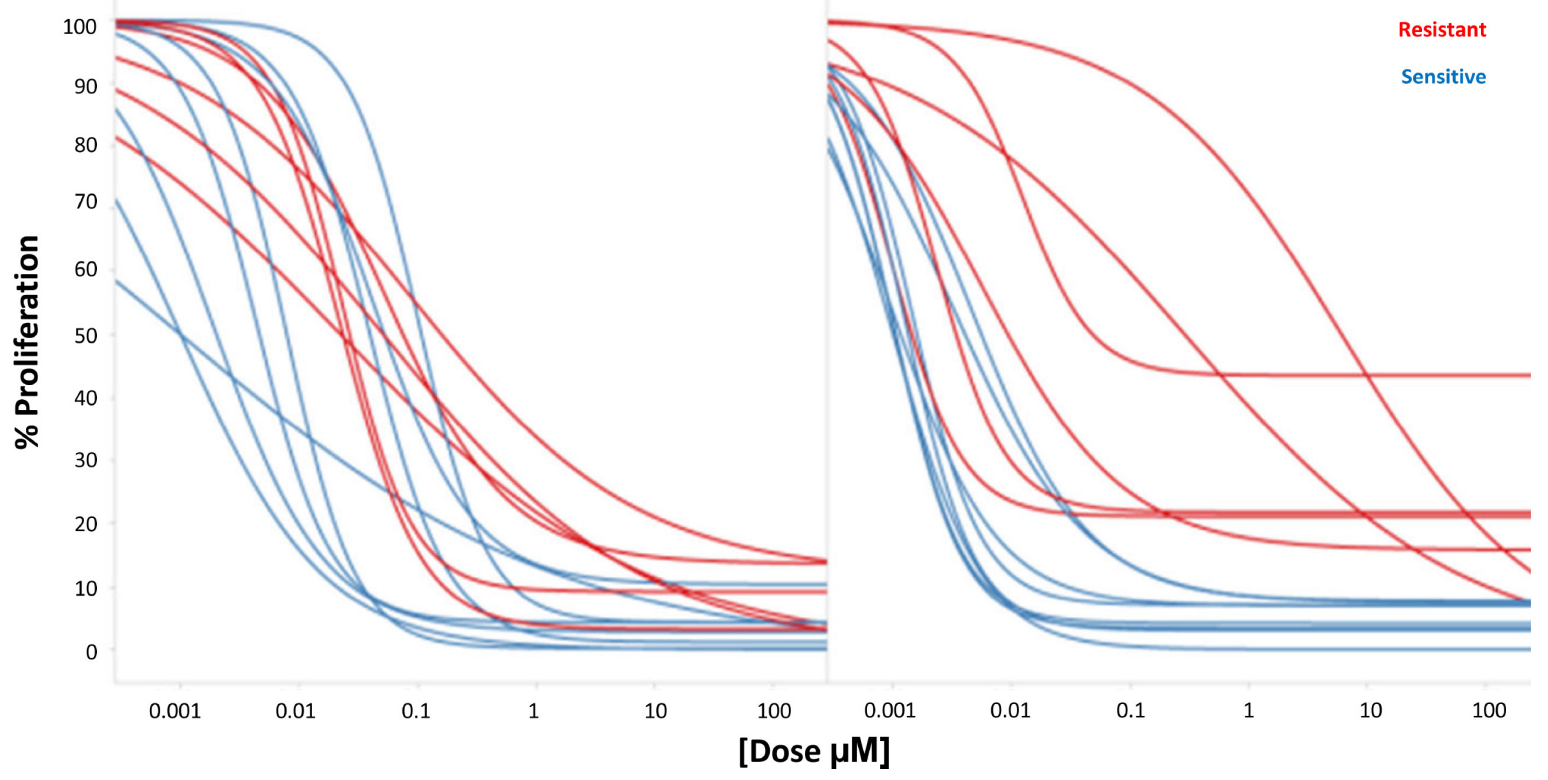

Figure 4: Simultaneous evaluation of Idelalisib and Ibrutinib. Cross reactivity of ibrutinib and idelalisib according to their ex vivo pharmacological profile. Red samples represent the ibrutinib resistant samples. 
Table 4: Ibrutinib and idelalisib pharmacological profile in the proliferative fraction according to their clinical and biological parameters

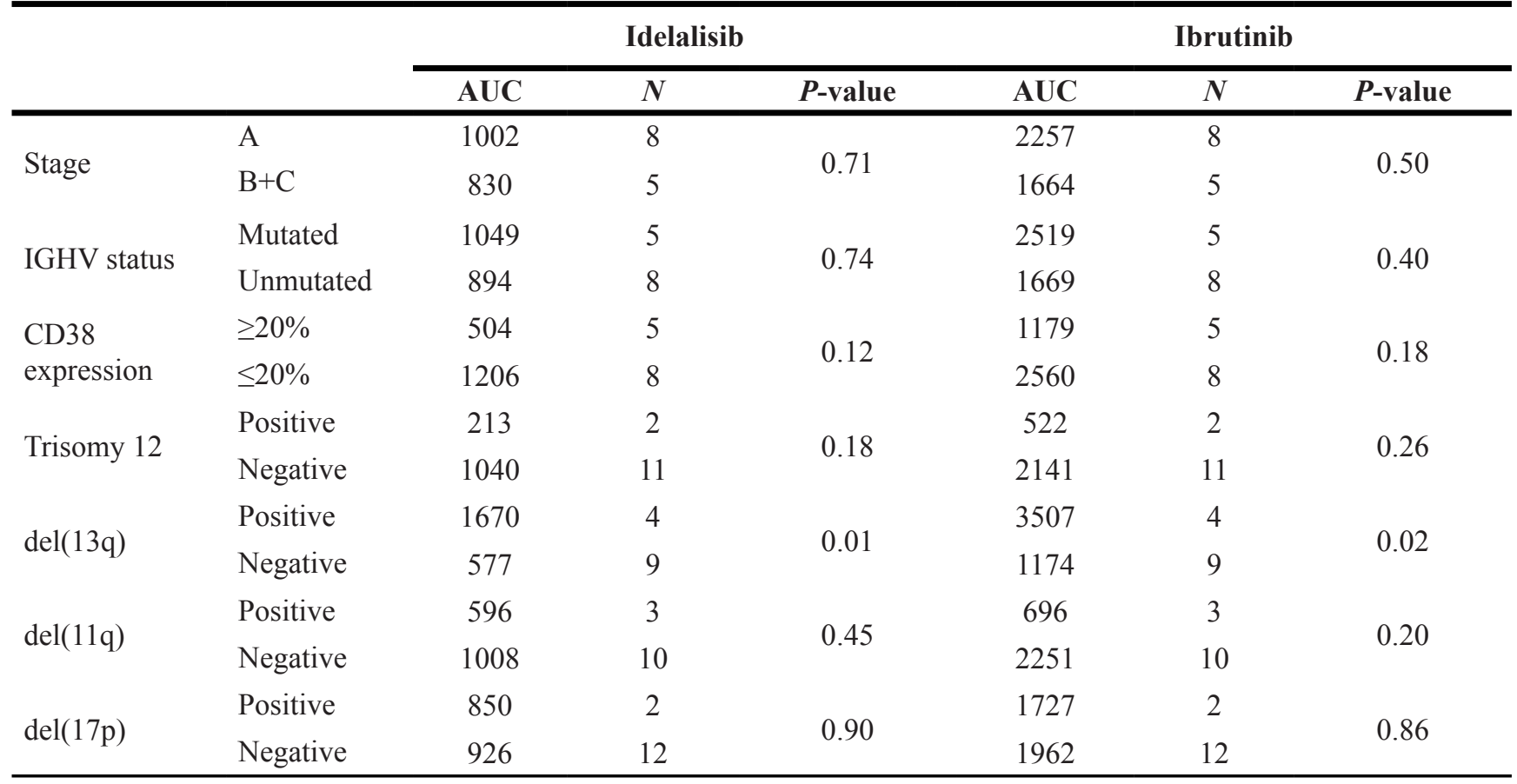

The latter could be further improved by the addition of the stroma cell line H5S and HS. Pooled CLL plasma were used to avoid interpatient variability, however future experiments should be performed to understand in detail the contributing factors affecting apoptosis induction and/ or proliferative capacity. In order to better mimick the in vivo microenvironment, and in particular to elicit cell proliferation as it occurs in vivo in the tissue proliferation centers, we also added cytokine combinations previously shown to be effective in increasing the fraction of leukemic cells in cycle. CpG and IL2 showed the best proliferative effect in the presence of the NE, stroma and human serum with a limited impact on cell survival, thus, collectively representing the best 'cocktail' for concomitantly studying proliferation and survival of CLL cells ex vivo. Contrary to previous reports [40-42], adding additional stimulatory B cell factors individually did not improve the overall assay conditions, suggesting that these factors may already be present and thus replaced in the CLL NE.

Altogether, our approach enabled developing an engineered microenvironment more realistically simulating the in vivo setting. Hence, the assay described here seems more appropriate for both ex vivo drug testing and ex vivo predicting the responses potentially achievable when administering the drug in vivo. Thanks to this assay, we were able to show that idelalisib has an antiproliferative effect on CLL cells, as recently suggested [43]. Similarly, we were also able to confirm the previous observation that ibrutinib targets CLL cell proliferation with very limited if any pro-apoptotic effect $[19,44]$; this supports that the results obtained in our novel assay for ex vivo drug testing are reliable. To further underscore the robustness of the assay, it should be noted that apoptosis was initially described in the case of ibrutinib or other signaling inhibitors (e.g. SYK inhibitors) only when these drugs were tested ex vivo on CLL cells in the absence of stromal support and/or at much higher concentration not attainable in vivo [45-49]. This does not contradict the fact that, in vivo, the typical mobilization effect of this novel class of drugs may indirectly favor apoptotic death due to the deprivation of prosurvival stimulation from the tissue microenvironment, including the stroma. More generally, the limited ex vivo propapoptotic effect may be reflected in the persistent lymphocytosis that may last for over a year [50-52].

Noticeably, the herein reported assay allows to identify patients where either drug may achieve less antiproliferative activity. In the case of ibrutinib, a few outlier samples were identified that required much higher doses to achieve an antiproliferative effect $\left(\mathrm{EC}_{50}\right.$ or potency); in the case of idelalisib, a higher percentage of proliferating cells persisted at very high doses compared to ibrutinib. If these differences are found to translate into differential clinical activity validated in a larger patient cohort, they may provide a future basis for selection between these drugs by simply screening peripheral blood samples prior to treatment initiation.

More importantly, neither drug was found to completely eliminate all CSFE ${ }^{\text {low }}$ proliferating cells in the tested cases. Indeed, a variable number of proliferating leukemic cells remained following either ibrutinib or idelalisib treatment, likely explaining the limited capacity 
of either drug to induce complete and profound responses $[32,34]$. In addition, this might indicate the existence of a fraction of CLL cells which are inherently resistant to these drugs. Whether such cells may be specifically and effectively targeted by drug combinations needs to be experimentally determined, potentially by capitalizing on the ability of our novel in vitro assay to pre-clinically test in a systematic fashion different plausible combinations. It will also be interesting to further exploit this assay to investigate if the CLL cases in which a larger fraction of cells appear to be non-responsive to the anti-proliferative effect of ibrutinib and idelalisib are actually those achieving less optimal clinical responses and if the depth of the response obtained in vivo may correlate to the percentage of cells responding ex vivo.

In conclusion, the herein described novel assay, enabling high-throughout exploration of combinations of drugs as well as real-time identification and separation of proliferating/non-proliferating cells, is expected to assist in predicting ex vivo the response to single or multiple drugs in each individual CLL patient requiring treatment. Although this needs to be tested prospectively, it opens up the potential of tailoring the drug or the dose to each individual patient.

\section{MATERIALS AND METHODS}

\section{Patient samples and Ethics statement}

Peripheral blood samples from 47 patients diagnosed with CLL according to the iwCLL guidelines [53] were obtained following informed consent in accordance with the Declaration of Helsinki. The study was approved by the local ethical committee of the participating centers. Table 1 shows the clinical parameters collected for each patient.

Peripheral blood mononuclear cells were separated by Ficoll Histopaque 1077 (Sigma-Aldrich, St. Louis, MO) density gradient and subsequently cryopreserved in fetal bovine serum (FBS; Thermo Fisher Scientific, Waltham, MA) plus 10\% dimethylsufoxide in liquid nitrogen until further analysis. After separation by density gradient, the plasma and the RBC from the peripheral blood of HD and CLL samples were also recovered. The plasma fractions were stored at $-80^{\circ} \mathrm{C}$ until use. RBCs were kept at $4^{\circ} \mathrm{C}$ for a maximum of 35 days with the addition of the anticoagulant citrate phosphate dextrose adenine solution (CPDA-1; Terumo Corporation, Tokyo, Japan) (150 $\mu \mathrm{l} \mathrm{CPDA} / \mathrm{ml}$ RBCs). These two fractions (plasma and RBCs) were added in combination to the cell culture media during the experimental procedures and referred to as NE.

\section{In vitro cell culture}

Frozen CLL samples were thawed and cultured in 96-well plates at a concentration of $10 \times 10^{6} \mathrm{cells} / \mathrm{ml}$ in
AIM-V AlbuMAX culture media that better support B-cell survival (Invitrogen, Carlsbad, CA) [54]. In order to test the best culture conditions in terms of proliferation and survival of leukemic cells, the following factors (either alone or concomitantly) were added to the wells:

FBS or HS (Sigma-Aldrich), at $10 \%$ or $20 \%$ concentration, 2\% HEPES, 1\% Zell Shield antibiotic (Labclinics, Barcelona, Spain), and 1\% L-glutamine $200 \mathrm{mM}$ (Lonza, Hopkinton, MA).

Cytokines/soluble molecules, in double or triple combinations: IL2 (Peprotech, London, United Kingdon), at $50 \mathrm{ng} / \mathrm{ml}$; IL21 (Peprotech, London, United Kingdon), at $25 \mathrm{ng} / \mathrm{ml}$; CpG ODN (ODN2006; Miltenyi Biotech, Bergisch Gladbach, Germany), at $1 \mu \mathrm{g} / \mathrm{ml}$; sCD40L (Peprotech, London, United Kingdon), at $1 \mu \mathrm{g} / \mathrm{ml}$; sCD40L plus enhancer (Enzo Life Sciences, Farmingdale, NY, USA), at $1 \mu \mathrm{g} / \mathrm{ml}$; BAFF (Peprotech, London, United Kingdon), $10 \mathrm{ng} / \mathrm{ml}$; anti-IgM+anti-IgG antibodies (Vitro, Sevilla, Spain), at $10 \mu \mathrm{g} / \mathrm{ml}$.

HS5 stromal cell line (ATCC ${ }^{\circledR}$ CRL-11882 ${ }^{\mathrm{TM}}$ ) was purchased from the American Type Culture Collection (ATCC; Rockville, MD). Cells were maintained at $37^{\circ} \mathrm{C}$ in 5\% $\mathrm{CO}_{2}$ atmosphere in Dulbecco's Modified Eagle's Medium (DMEM; Sigma) supplemented with $2 \mathrm{mM}$ L-Glutamine, 1\% penicillin/streptomycin (Sigma-Aldrich) and $10 \%$ heat-inactivated FBS. Early passages of the cell line were used for the experiments. Cells were plated in 96-well plates and incubated for 24 hours to allow cells to adhere. $1 \times 10^{4} \mathrm{CLL}$ cells were then cultured at a ratio of 100:1 (B-Cells:HS5) on confluent layers of the stroma.

$\mathrm{NE}$; plasma and $\mathrm{RBC}$ of $\mathrm{NE}$ were also added in combination at a concentration of $1 \mu \mathrm{l} / 60 \mu \mathrm{l}$. 0,5 $\mu \mathrm{l}$ from a pooled RBC plus $0,5 \mu \mathrm{l}$ from a pooled plasma were added in a final $60 \mu \mathrm{l}$ volume.

Cultures were harvested after $96 \mathrm{~h}$ for survival and proliferation analysis.

\section{Apoptosis and viability assays}

To lyse RBCs, $180 \mathrm{~mL}$ of ammonium chloride lysis solution was added to each well (2 $\mathrm{g} \mathrm{KHCO}_{3}$, $16.58 \mathrm{~g} \mathrm{NH}_{4} \mathrm{Cl}, 0.074 \mathrm{~g} \mathrm{Na}_{2}$-ethylenediaminetetraacetic acid [EDTA] $2 \mathrm{H}_{2} \mathrm{O}, \mathrm{H}_{2} \mathrm{O}$ to $1 \mathrm{~L}$ ). Following 10 minute incubation at $4^{\circ} \mathrm{C}$, each plate was centrifuged for 5 minutes at $1200 \mathrm{rpm}$ and the supernatant removed. The lysis step was performed twice. For staining, $20 \mu \mathrm{l}$ of a combination of annexin-V CF Blue (Immunostep, Salamanca, Spain), CD19 PC7 (Clone J4.119, Beckman Coulter, Brea, CA) and CD45-APC (clon HI30, Immunostep) resupended in binding buffer (BB) (2.4 g HEPES, $8.19 \mathrm{~g} \mathrm{NaCl}, 0.37 \mathrm{~g} \mathrm{Cl}_{2} \mathrm{Ca}, \mathrm{H}_{2} \mathrm{O}$ to $1 \mathrm{~L}$ ) were added. After 15 minutes of incubation at room temperature in the dark, a wash step was performed using BB solution. The pellet was resuspended in $80 \mu \mathrm{L}$ $\mathrm{BB}$ for cytofluorimetric analysis utilizing PharmaFlow platform, as previously reported [29]. Apoptotic cells was 
measured as the percentage of Annexin V positive cells subtracting the value of the apoptotic cells after thaw. In selected experiments, 7-amino-actinomycin (7-AAD) (BD Biosciences) was added to confirm the Annexin- $\mathrm{V}$ results (See Supplementary Figure 3).

\section{Proliferation assay}

The Vybrant ${ }^{\circledR}$ CFDA SE Cell Tracer Kit (Invitrogen) was used to measure cell proliferation. The CFDA SE (component A) was dissolved in dimethylsufoxide (component B) at a concentration of $5 \mathrm{mM}$ as stock solution and kept at $-20^{\circ} \mathrm{C}$ until further use. CLL cells were adjusted at $10 \times 10^{6}$ cells $/ \mathrm{ml}$ in AIM-V AlbuMAX culture media without FBS. CFSE was added to a $1 \mathrm{ml}$ cell suspension at a final concentration of $5 \mu \mathrm{M}$. After addition of CFSE, cells were vortexed and incubated at room temperature for 10 min with continuous shaking and light protected. At the end of the incubation period, the cells were resuspended in cold culture media with $10 \%$ FBS (complete culture media) and kept on ice for $5 \mathrm{~min}$ following two washes in cold complete culture media and maintained at $4^{\circ} \mathrm{C}$ until cytofluorimetric analysis in the PharmaFlow platform, as previously described [29]. Percentage of proliferation is defined as the percent of B-cells that have lost any level of CFDA labeling in the presence of exogenous stimuli.

\section{Drug assay activity testing}

Cryopreserved CLL samples were diluted with AIM-V AlbuMAX (Invitrogen) supplemented with the NE, $10 \%$ of human serum (Sigma-Aldrich), 2\% HEPES, 1\% Zell Shield antibiotic (Labclinics), 1\% L-glutamine 200 $\mathrm{mM}$ (Lonza), $1 \mu \mathrm{g} / \mathrm{ml} \mathrm{CpG} \mathrm{ODN}$ and $50 \mathrm{ng} / \mathrm{ml}$ IL2. This mixture was dispensed into 96-well plates containing the HS5 (100:1) cell line and transferred into a new 96-well plate containing idelalisib (Selleck Chemicals, Houston, TX) and ibrutinib (Selleck Chemicals). Drug plates were prepared using an Echo 550 Liquid Handler (LabCyte, Sunnyvale, CA). For each drug, 8 concentrations were used. The plates were incubated for 96 hours at $37^{\circ} \mathrm{C}$ in humidified air containing $5 \% \mathrm{CO}_{2}$. Later, proliferation and viability were tested by flow cytometry in the PharmaFlow platform as indicated above.

Using the automated cell dispensing system Multidrop (Thermofisher), a precise constant number of leukemic cells is seeded in every well, all wells containing the same number of leukemic cells. This enables assessing compound activity by counting the absolute number of leukemic cells in each well by a proprietary automated flow cytometry platform described elsewhere [29], and comparing wells with a certain concentration of compound vs control wells without compound. Eight concentrations of each drug are used to calculate dose response curves to measure the compound activity. In order to identify live CLL cells, once the CLL cell subpopulation has been gated, Annexin V expression and FSC/SSC parameter is used to exclude apoptotic cells. Therefore, absolute counts of only non apoptotic leukemic cells is compared between different wells. This methodology is mechanistically unbiased measuring simultaneously in the same cell population both depletion and proliferaton of cells, as a decrease of non-proliferating cell counts (NP) or an increase in proliferating (PR) cell counts, respectively. Because we count only non apoptotic leukemic cells, we use the term Survival, normalized to the number of non apoptotic leukemic cells in the control cells as \% Survival. This allows to plot in the same graph both proliferating and non-proliferating cells measured in the same well under the same conditions using the same cell counting method, as shown in Figure 3; it shows the difference in the dose response curves between NP vs PR cells using this same \% Survival value in the Y axis.

Gate strategy and representative dot plots are provided (See Supplementary Figure 4) for the analysis of cell survival and proliferation.

\section{Statistical analysis}

In order to determine the statistical significance of the differences observed between groups, the MannWhitney U and Wilcoxon tests were used. Drug potency and efficacy was estimated by a modelling approach to dose-response pharmacodynamics function. The model used (Equation 1) to fit the data was the most common single-site sigmoidal dose-response inhibitory model based on Hill equation, where the dependent variable (y) analyzed was the number of live CLL cells counted by flow-cytometry at every tested concentration of drug. Data points were fitted using the Levenburg Marquardt algorithm. Normalization of the results to calculate the survival index was performed referring each data point to the basal level parameter (E0). This approach allows the calculation of the normalized AUC value by integrating the curve function from the model between the lowest and highest concentrations.

$$
y=A+\frac{B-A}{1+\left(\frac{C}{x}\right)^{D}}
$$

$\mathrm{A}$ is the basal or $\mathrm{E}_{0}, \mathrm{~B}$ is the $\mathrm{E}_{\max }, \mathrm{C}$ is the $\mathrm{EC}_{50}$ and D the slope or Hill factor.

\section{Abbreviations}

CLL: Chronic Lymphocytic Leukemia; NE: Native Environment; HD: Healthy Donors; HS: Human Serum; U-CLL: IGHV Unmutated CLL; M-CLL: IGHV Mutated CLL; AUC: Area Under the Curve; CR: Complete Response; RBC: Red Blood Cell; CPDA: Citrate phosphate dextrose adenine; ATCC: American Type 
Culture Collection; DMEN: Dulbecco's Modified Eagle's Medium; BB: Binding Buffer.

\section{Author contributions}

D.P. performed experiments, analyzed the data, and wrote the manuscript. L.S., A.X., M.M., P.R., J.M., J.S., M.G., A.C., E.A., I.S., contributed samples/patient data and provided critical input. A.B.E. performed experiments. A.R., J.G., performed the statistical analyses. V.M., C.Q., S.T., supervised research. R.R., K.S., J.B., P.G., designed the study, supervised research, and wrote the paper. All authors contributed to the preparation of the manuscript and approved the submission in its current form.

\section{ACKNOWLEDGMENTS}

We would like to thank the patients for providing their samples. We also thank our lab scientists for working always with high rigor and efficiency.

\section{CONFLICTS OF INTEREST}

KS receives unrestricted research support from Gilead Sciences, Janssen Pharmaceuticals and Novartis SA. PG receives unrestricted research support from Gilead Sciences, GSK/Novartis and Celgene. Vivia has received unrestricted research support from Gilead.

\section{FUNDING}

This work was supported in part by H2020 "MEDGENET, Medical Genomics and Epigenomics Network" (Grant 692298), funded by the European Union; the Swedish Cancer Society, the Swedish Research Council, and Lion's Cancer Research Foundation; Associazione Italiana per la Ricerca sul Cancro AIRC (Investigator Grant \#20246 to PG and Special Program Molecular Clinical Oncology - 5 per mille \#9965), Milano, Italy, Ricerca; ERA-NET TRANSCAN-2 JTC 2016, GCH-CLL. Vivia has received unrestricted research support from Gilead.

\section{REFERENCES}

1. Caligaris-Cappio F, Ghia P. Novel insights in chronic lymphocytic leukemia: are we getting closer to understanding the pathogenesis of the disease? J Clin Oncol. 2008; 26:4497-4503.

2. Burger JA, Ghia P, Rosenwald A, Caligaris-Cappio F. The microenvironment in mature B-cell malignancies: a target for new treatment strategies. Blood. 2009; 114:3367-3375.

3. Caligaris-Cappio F, Bertilaccio MT, Scielzo C. How the microenvironment wires the natural history of chronic lymphocytic leukemia. Semin Cancer Biol. 2014; 24:43-48.
4. Lagneaux L, Delforge A, Bron D, De Bruyn C, Stryckmans P. Chronic lymphocytic leukemic B cells but not normal B cells are rescued from apoptosis by contact with normal bone marrow stromal cells. Blood. 1998; 91:2387-2396.

5. Burger JA, Tsukada N, Burger $M$, Zvaifler NJ, Dell'Aquila M, Kipps TJ. Blood-derived nurse-like cells protect chronic lymphocytic leukemia B cells from spontaneous apoptosis through stromal cell-derived factor-1. Blood. 2000; 96:2655-2663.

6. Ghia P, Strola G, Granziero L, Geuna M, Guida G, Sallusto F, Ruffing N, Montagna L, Piccoli P, Chilosi M, CaligarisCappio F. Chronic lymphocytic leukemia B cells are endowed with the capacity to attract CD4+, CD40L + T cells by producing CCL22. Eur J Immunol. 2002; 32:1403-1413.

7. Ghia P, Circosta P, Scielzo C, Vallario A, Camporeale A, Granziero L, Caligaris-Cappio F. Differential effects on CLL cell survival exerted by different microenvironmental elements. Curr Top Microbiol Immunol. 2005; 294:135-145.

8. Kay NE, Shanafelt TD, Strege AK, Lee YK, Bone ND, Raza A. Bone biopsy derived marrow stromal elements rescue chronic lymphocytic leukemia B-cells from spontaneous and drug induced cell death and facilitates an “angiogenic switch”. Leuk Res. 2007; 31:899-906.

9. Kurtova AV, Balakrishnan K, Chen R, Ding W, Schnabl S, Quiroga MP, Sivina M, Wierda WG, Estrov Z, Keating MJ, Shehata M, Jager U, Gandhi V, et al. Diverse marrow stromal cells protect CLL cells from spontaneous and drug-induced apoptosis: development of a reliable and reproducible system to assess stromal cell adhesionmediated drug resistance. Blood. 2009; 114:4441-4450.

10. Plander M, Seegers S, Ugocsai P, Diermeier-Daucher S, Ivanyi J, Schmitz G, Hofstadter F, Schwarz S, Orso E, Knuchel R, Brockhoff G. Different proliferative and survival capacity of CLL-cells in a newly established in vitro model for pseudofollicles. Leukemia. 2009; 23:2118-2128.

11. Purroy N, Abrisqueta P, Carabia J, Carpio C, Palacio C, Bosch F, Crespo M. Co-culture of primary CLL cells with bone marrow mesenchymal cells, CD40 ligand and $\mathrm{CpG}$ ODN promotes proliferation of chemoresistant CLL cells phenotypically comparable to those proliferating in vivo. Oncotarget. 2015; 6:7632-43. https://doi.org/10.18632/ oncotarget.2939.

12. Pascutti MF, Jak M, Tromp JM, Derks IA, Remmerswaal EB, Thijssen R, van Attekum MH, van Bochove GG, Luijks DM, Pals ST, van Lier RA, Kater AP, van Oers $\mathrm{MH}$, et al. IL-21 and CD40L signals from autologous $\mathrm{T}$ cells can induce antigen-independent proliferation of CLL cells. Blood. 2013; 122:3010-3019.

13. Decker T, Peschel C. Effect of immunostimulatory CpGoligonucleotides in chronic lymphocytic leukemia B cells. Leuk Lymphoma. 2001; 42:301-307.

14. Heerema NA, Byrd JC, Dal Cin PS, Dell' Aquila ML, Koduru PR, Aviram A, Smoley SA, Rassenti LZ, Greaves 
AW, Brown JR, Rai KR, Kipps TJ, Kay NE, Van Dyke DL, and Chronic Lymphocytic Leukemia Research Consortium. Stimulation of chronic lymphocytic leukemia cells with CpG oligodeoxynucleotide gives consistent karyotypic results among laboratories: a CLL Research Consortium (CRC) Study. Cancer Genet Cytogenet. 2010; 203:134-140.

15. Purroy N, Carabia J, Abrisqueta P, Egia L, Aguilo M, Carpio C, Palacio C, Crespo M, Bosch F. Inhibition of BCR signaling using the Syk inhibitor TAK-659 prevents stroma-mediated signaling in chronic lymphocytic leukemia cells. Oncotarget. 2017; 8:742-56. https://doi.org/10.18632/ oncotarget. 13557.

16. Herman SE, Gordon AL, Wagner AJ, Heerema NA, Zhao W, Flynn JM, Jones J, Andritsos L, Puri KD, Lannutti BJ, Giese NA, Zhang X, Wei L, et al. Phosphatidylinositol 3-kinase-delta inhibitor CAL-101 shows promising preclinical activity in chronic lymphocytic leukemia by antagonizing intrinsic and extrinsic cellular survival signals. Blood. 2010; 116:2078-2088.

17. Hoellenriegel J, Meadows SA, Sivina M, Wierda WG, Kantarjian H, Keating MJ, Giese N, O'Brien S, Yu A, Miller LL, Lannutti BJ, Burger JA. The phosphoinositide 3'-kinase delta inhibitor, CAL-101, inhibits B-cell receptor signaling and chemokine networks in chronic lymphocytic leukemia. Blood. 2011; 118:3603-3612.

18. Ponader S, Chen SS, Buggy JJ, Balakrishnan K, Gandhi V, Wierda WG, Keating MJ, O'Brien S, Chiorazzi N, Burger JA. The Bruton tyrosine kinase inhibitor PCI32765 thwarts chronic lymphocytic leukemia cell survival and tissue homing in vitro and in vivo. Blood. 2012; 119:1182-1189.

19. Cheng S, Ma J, Guo A, Lu P, Leonard JP, Coleman M, Liu M, Buggy JJ, Furman RR, Wang YL. BTK inhibition targets in vivo CLL proliferation through its effects on B-cell receptor signaling activity. Leukemia. 2014; 28:649-657.

20. Herman SE, Mustafa RZ, Gyamfi JA, Pittaluga S, Chang S, Chang B, Farooqui M, Wiestner A. Ibrutinib inhibits BCR and NF-kappaB signaling and reduces tumor proliferation in tissue-resident cells of patients with CLL. Blood. 2014; 123:3286-3295.

21. de Rooij MF, Kuil A, Geest CR, Eldering E, Chang BY, Buggy JJ, Pals ST, Spaargaren M. The clinically active BTK inhibitor PCI-32765 targets B-cell receptor- and chemokine-controlled adhesion and migration in chronic lymphocytic leukemia. Blood. 2012; 119:2590-2594.

22. Niemann CU, Herman SE, Maric I, Gomez-Rodriguez J, Biancotto A, Chang BY, Martyr S, Stetler-Stevenson M, Yuan CM, Calvo KR, Braylan RC, Valdez J, Lee YS, et al. Disruption of in vivo Chronic Lymphocytic Leukemia Tumor-Microenvironment Interactions by Ibrutinib-Findings from an Investigator-Initiated Phase II Study. Clin Cancer Res. 2016; 22:1572-1582.

23. Dubovsky JA, Beckwith KA, Natarajan G, Woyach JA, Jaglowski S, Zhong Y, Hessler JD, Liu TM, Chang BY,
Larkin KM, Stefanovski MR, Chappell DL, Frissora FW, et al. Ibrutinib is an irreversible molecular inhibitor of ITK driving a Th1-selective pressure in T lymphocytes. Blood. 2013; 122:2539-2549.

24. Fiorcari S, Maffei R, Audrito V, Martinelli S, Ten Hacken E, Zucchini P, Grisendi G, Potenza L, Luppi M, Burger JA, Deaglio S, Marasca R. Ibrutinib modifies the function of monocyte/macrophage population in chronic lymphocytic leukemia. Oncotarget. 2016; 7:65968-81. https://doi. org/10.18632/oncotarget.11782.

25. Herman SE, Gordon AL, Hertlein E, Ramanunni A, Zhang X, Jaglowski S, Flynn J, Jones J, Blum KA, Buggy JJ, Hamdy A, Johnson AJ, Byrd JC. Bruton tyrosine kinase represents a promising therapeutic target for treatment of chronic lymphocytic leukemia and is effectively targeted by PCI-32765. Blood. 2011; 117:6287-6296.

26. Amin N, Balasubramanian S, Saiya-Cork K, Shedden K, Hu N, Malek S. Cell-intrinsic determinants of ibrutinib-induced apoptosis in Chronic Lymphocytic Leukemia. Clin Cancer Res. 2017; 23:1049-1059.

27. Wodarz D, Garg N, Komarova NL, Benjamini O, Keating MJ, Wierda WG, Kantarjian H, James D, O'Brien S, Burger JA. Kinetics of CLL cells in tissues and blood during therapy with the BTK inhibitor ibrutinib. Blood. 2014; 123:4132-4135.

28. Chen SS, Chang BY, Chang S, Tong T, Ham S, Sherry B, Burger JA, Rai KR, Chiorazzi N. BTK inhibition results in impaired CXCR4 chemokine receptor surface expression, signaling and function in chronic lymphocytic leukemia. Leukemia. 2016; 30:833-843.

29. Bennett TA, Montesinos P, Moscardo F, MartinezCuadron D, Martinez J, Sierra J, Garcia R, de Oteyza JP, Fernandez P, Serrano J, Fernandez A, Herrera P, Gonzalez A, et al. Pharmacological profiles of acute myeloid leukemia treatments in patient samples by automated flow cytometry: a bridge to individualized medicine. Clin Lymphoma Myeloma Leuk. 2014; 14:305-318.

30. Byrd JC, Furman RR, Coutre SE, Flinn IW, Burger JA, Blum KA, Grant B, Sharman JP, Coleman M, Wierda WG, Jones JA, Zhao W, Heerema NA, et al. Targeting BTK with ibrutinib in relapsed chronic lymphocytic leukemia. N Engl J Med. 2013; 369:32-42.

31. Burger JA, Tedeschi A, Barr PM, Robak T, Owen C, Ghia P, Bairey O, Hillmen P, Bartlett NL, Li J, Simpson D, Grosicki S, Devereux S, et al. Ibrutinib as Initial Therapy for Patients with Chronic Lymphocytic Leukemia. N Engl J Med. 2015; 373:2425-2437.

32. Byrd JC, Brown JR, O'Brien S, Barrientos JC, Kay NE, Reddy NM, Coutre S, Tam CS, Mulligan SP, Jaeger U, Devereux S, Barr PM, Furman RR, et al. Ibrutinib versus ofatumumab in previously treated chronic lymphoid leukemia. N Engl J Med. 2014; 371:213-223.

33. Brown JR, Byrd JC, Coutre SE, Benson DM, Flinn IW, Wagner-Johnston ND, Spurgeon SE, Kahl BS, Bello C, Webb HK, Johnson DM, Peterman S, Li D, et al. Idelalisib, an inhibitor of phosphatidylinositol 3-kinase p110delta, for 
relapsed/refractory chronic lymphocytic leukemia. Blood. 2014; 123:3390-3397.

34. Furman RR, Sharman JP, Coutre SE, Cheson BD, Pagel JM, Hillmen P, Barrientos JC, Zelenetz AD, Kipps TJ, Flinn I, Ghia P, Eradat H, Ervin T, et al. Idelalisib and rituximab in relapsed chronic lymphocytic leukemia. N Engl J Med. 2014; 370:997-1007.

35. O’Brien SM, Lamanna N, Kipps TJ, Flinn I, Zelenetz AD, Burger JA, Keating M, Mitra S, Holes L, Yu AS, Johnson DM, Miller LL, Kim Y, et al. A phase 2 study of idelalisib plus rituximab in treatment-naive older patients with chronic lymphocytic leukemia. Blood. 2015; 126:2686-2694.

36. Roberts AW, Davids MS, Pagel JM, Kahl BS, Puvvada SD, Gerecitano JF, Kipps TJ, Anderson MA, Brown JR, Gressick L, Wong S, Dunbar M, Zhu M, et al. Targeting BCL2 with Venetoclax in Relapsed Chronic Lymphocytic Leukemia. N Engl J Med. 2016; 374:311-322.

37. Balakrishnan K, Peluso M, Fu M, Rosin NY, Burger JA, Wierda WG, Keating MJ, Faia K, O’Brien S, Kutok JL, Gandhi V. The phosphoinositide-3-kinase (PI3K)-delta and gamma inhibitor, IPI-145 (Duvelisib), overcomes signals from the PI3K/AKT/S6 pathway and promotes apoptosis in CLL. Leukemia. 2015; 29:1811-1822.

38. Sharman J, Hawkins M, Kolibaba K, Boxer M, Klein L, Wu M, Hu J, Abella S, Yasenchak C. An open-label phase 2 trial of entospletinib (GS-9973), a selective spleen tyrosine kinase inhibitor, in chronic lymphocytic leukemia. Blood. 2015; 125:2336-2343.

39. Byrd JC, Harrington B, O'Brien S, Jones JA, Schuh A, Devereux S, Chaves J, Wierda WG, Awan FT, Brown JR, Hillmen P, Stephens DM, Ghia P, et al. Acalabrutinib (ACP196) in Relapsed Chronic Lymphocytic Leukemia. N Engl J Med. 2016; 374:323-332.

40. Cols M, Barra CM, He B, Puga I, Xu W, Chiu A, Tam W, Knowles DM, Dillon SR, Leonard JP, Furman RR, Chen K, Cerutti A. Stromal endothelial cells establish a bidirectional crosstalk with chronic lymphocytic leukemia cells through the TNF-related factors BAFF, APRIL, and CD40L. J Immunol. 2012; 188:6071-6083.

41. Burgess M, Cheung C, Chambers L, Ravindranath K, Minhas G, Knop L, Mollee P, McMillan NA, Gill D. CCL2 and CXCL2 enhance survival of primary chronic lymphocytic leukemia cells in vitro. Leuk Lymphoma. 2012; 53:1988-1998.

42. Ghamlouch H, Ouled-Haddou H, Damaj G, Royer B, Gubler B, Marolleau JP. A combination of cytokines rescues highly purified leukemic CLL B-cells from spontaneous apoptosis in vitro. PLoS One. 2013; 8:e60370.

43. Slinger E, Thijssen R, Kater AP, Eldering E. Targeting antigenindependent proliferation in chronic lymphocytic leukemia through differential kinase inhibition. Leukemia. 2017; 31:2601-07.

44. Guo A, Lu P, Galanina N, Nabhan C, Smith SM, Coleman M, Wang YL. Heightened BTK-dependent cell proliferation in unmutated chronic lymphocytic leukemia confers increased sensitivity to ibrutinib. Oncotarget. 2016; 7:4598-610. https://doi.org/10.18632/oncotarget.6727.
45. Hoellenriegel J, Coffey GP, Sinha U, Pandey A, Sivina M, Ferrajoli A, Ravandi F, Wierda WG, O’Brien S, Keating MJ, Burger JA. Selective, novel spleen tyrosine kinase (Syk) inhibitors suppress chronic lymphocytic leukemia B-cell activation and migration. Leukemia. 2012; 26:1576-1583.

46. Friedberg JW, Sharman J, Sweetenham J, Johnston PB, Vose JM, Lacasce A, Schaefer-Cutillo J, De Vos S, Sinha R, Leonard JP, Cripe LD, Gregory SA, Sterba MP, et al. Inhibition of Syk with fostamatinib disodium has significant clinical activity in non-Hodgkin lymphoma and chronic lymphocytic leukemia. Blood. 2010; 115:2578-2585.

47. Cheng S, Coffey G, Zhang XH, Shaknovich R, Song Z, Lu P, Pandey A, Melnick AM, Sinha U, Wang YL. SYK inhibition and response prediction in diffuse large B-cell lymphoma. Blood. 2011; 118:6342-6352.

48. Coffey G, DeGuzman F, Inagaki M, Pak Y, Delaney SM, Ives D, Betz A, Jia ZJ, Pandey A, Baker D, Hollenbach SJ, Phillips DR, Sinha U. Specific inhibition of spleen tyrosine kinase suppresses leukocyte immune function and inflammation in animal models of rheumatoid arthritis. J Pharmacol Exp Ther. 2012; 340:350-359.

49. Herman SE, Barr PM, McAuley EM, Liu D, Wiestner A, Friedberg JW. Fostamatinib inhibits B-cell receptor signaling, cellular activation and tumor proliferation in patients with relapsed and refractory chronic lymphocytic leukemia. Leukemia. 2013; 27:1769-1773.

50. Herman SE, Niemann CU, Farooqui M, Jones J, Mustafa RZ, Lipsky A, Saba N, Martyr S, Soto S, Valdez J, Gyamfi JA, Maric I, Calvo KR, et al. Ibrutinib-induced lymphocytosis in patients with chronic lymphocytic leukemia: correlative analyses from a phase II study. Leukemia. 2014; 28:2188-2196.

51. Woyach JA, Smucker K, Smith LL, Lozanski A, Zhong Y, Ruppert AS, Lucas D, Williams K, Zhao W, Rassenti L, Ghia E, Kipps TJ, Mantel R, et al. Prolonged lymphocytosis during ibrutinib therapy is associated with distinct molecular characteristics and does not indicate a suboptimal response to therapy. Blood. 2014; 123:1810-1817.

52. Byrd JC, Furman RR, Coutre SE, Burger JA, Blum KA, Coleman M, Wierda WG, Jones JA, Zhao W, Heerema NA, Johnson AJ, Shaw Y, Bilotti E, et al. Three-year follow-up of treatment-naive and previously treated patients with CLL, SLL receiving single-agent ibrutinib. Blood. 2015; 125:2497-2506.

53. Hallek M, Cheson BD, Catovsky D, Caligaris-Cappio F, Dighiero G, Dohner H, Hillmen P, Keating MJ, Montserrat E, Rai KR, Kipps TJ. Guidelines for the diagnosis and treatment of chronic lymphocytic leukemia: a report from the International Workshop on Chronic Lymphocytic Leukemia updating the National Cancer Institute-Working Group 1996 guidelines. Blood. 2008; 111:5446-5456.

54. Levesque MC, O'Loughlin CW, Weinberg JB. Use of serum-free media to minimize apoptosis of chronic lymphocytic leukemia cells during in vitro culture. Leukemia. 2001; 15:1305-1307. 